\title{
Irradiated Blood Product
}

National Cancer Institute

\section{Source}

National Cancer Institute. Irradiated Blood Product. NCI Thesaurus. Code C133275.

Irradiation of blood products before transfusion. 